\title{
Assessment of Combining Ability Effects for Several Yield and Quality Traits in a Complete Diallel Cross of Strawberry (Fragaria $\times$ ananassa Duch.)
}

\author{
Sorin CIULCA*, Natalia CARP, Emilian MADOŞA, Adriana CIULCA, \\ Radu ŞUMĂLAN
}

\begin{abstract}
Banat's University of Agricultural Sciences and Veterinary Medicine "King Michael I of Romania" Timisoara, Faculty of Horticulture and Forestry, 119 Calea Aradului, 300365, Timisoara,_Romania; c_i_sorin@yahoo.com (*correspondingauthor); c_naty_ivy@yahoo.com; madosae@yahoo.com; adrianaciulca@gmail.com;sumalanagro@yahoo.com.
\end{abstract}

\begin{abstract}
Information on the inheritance of yield and quality traits is important for the selection of parents and breeding approaches to be adopted for the improvement of strawberry. The present study aimed to estimate the combining ability and gene effects for plant yield, fruits number/plant, fruit weight, pulp firmness and sugar content of strawberries in order to identify the best genitors and promising crosses, in 30 hybrids of six parents. The additive and non-additive gene action as well as the maternal effects was involved in the inheritance of the studied traits. For all traits, especially for fruit weight and plant yield, the additive gene action was more important than the non-additive one. The parents 'Al' and 'Alba' showed a higher concentration of favourable alleles for plant yield and fruits number, and they will allow the increase of plant yield when used as a donor of pollen and the increase of fruit number when used as a recipient of pollen. The variety 'Marmolada' was a good general combiner for sugar content, pulp firmness and fruit weight, especially when used as a female genitor. These parents could be used in hybridization in order to accelerate the genetic improvement of some yield and quality traits in strawberries. The cross 'Mira' $\times$ 'Onda' expressed desirable specific combining ability effects for yield traits and can be successfully use in strawberries breeding programs. In the case of 'Alba' $\times$ 'Clery' there is a high probability to select progenies with valuable yield traits associated with sweet fruits.
\end{abstract}

Keywords: GCA, SCA, inheritance quantitative traits, strawberry breeding

\section{Introduction}

Strawberries (Fragaria $\times$ ananassa Duch.) are cultivated worldwide for their fruit, and are widely appreciated for their characteristic aroma and sweetness. The production and consumption of strawberries is increasing because of their food value (Ara et al., 2009) and currently strawberries comprise more than 500 commercial cultivars grown worldwide (Hancock, 1999).

In strawberry production, fruit quality and yield depend on many factors, e.g. the cultivar, weather conditions during the growing season and above all agronomic practices (Paszko et al., 2014). The yield ability in strawberries is a very complex trait that relies on the influence and contribution of several components, such as number and size of fruits, plant vigour, hardiness, and disease resistance of the plant (Hancock et al., 2008). The number of fruits is dependent on flower formation and development. In this regard phytohormones such as auxin and cytokinins have been shown to play an important role in floral induction and differentiation (Hou and Huang, 2005; Eshghi and Tafazoli, 2007). The size of the fruit is controlled by the dimension of the receptacle and number of achenes. The plants with large fruits have bigger leaves, a larger photosynthetic area, and thicker petioles and flower stalks (Hortyński et al., 1991). These components must be combined in order to ensure higher levels of yield and a high amount of marketable fruits (Carp and Ciulca, 2016).

Fruit firmness is one of the most important quality traits of strawberry negative correlated with flavor emission (Salentijn et al., 2003), and positive correlated with time of flowering and fruit glossiness (Ukalska et al., 2006). This trait is highly variable and affected by genetic background, growing conditions, degree of ripeness, post-harvest handling, internal temperature etc. (Doving et al., 2005). 
518

Considering that glucose, fructose and sucrose are the main sugars in strawberry fruits, Shaw (1988) reported small differences in total sugars, but a significant genotypic variation in the content of sucrose, glucose and fructose in his breeding population. Fruit sweetness is slightly correlated with skin and flesh colour (Shaw, 1991).

Strawberry yield and quality traits are polygenic inherited and greatly influenced by environmental condition. Strawberries productivity and quality are commonly limited by several environmental factors including: heat and drought, salinity, winter cold, spring frosts and insufficient chilling hours (Hancock et al., 2008). It was estimated that abiotic stress conditions can potentially reduce the yield of strawberry plants by more than $50 \%$ (Vij and Tyagi, 2007). Considering that the yield traits are often associated with low quality of fruits, the genotypes rarely associate production efficiency and sensorial quality with the nutritional values of fruit, probably because the most breeding programmes consider nutritional characters as a minor priority (Capocasa et al., 2008).

The efficiency of a breeding program depends mostly by the selection of the best parents in order to improve different traits. The analysis of general combining ability (GCA) and specific combining ability (SCA) effects is a useful tool in the selection of the best parents and superior hybrids. The differences in the GCA are mainly due to the additive genetic effects and higher order additive interactions, while the differences in SCA are attributed to the non-additive effects, dominance and different types of epistasis (Falconer, 1989). If both the GCA and SCA values are not significant, epistatic gene effects may play an important role in determining different traits (Fehr, 1993). The most promising hybrids are those that coming from the crossing of divergent parents, where at least one of them presented high GCA (Cruz and Vencovsky, 1989).

The diallel mating design can be used to estimate GCA, SCA and heritability for a trait in a population derived from fixed, or non-random parents (Hill et al., 1998; Hakizimana et al., 2004). The analysis of diallel cross by the method of Griffing (1956b) which partition the total genetic variation into GCA of the parents and SCA of the crosses have been widely used in strawberry breeding (Daubeny, 1961; Hsu et al., 1969; Spangelo et al., 1971; MacLachlan, 1978; McNicol and Gooding, 1979; Simpson, 1987; Fort and Shaw, 2000; Davik and Honne, 2005: Masny et al., 2005; Bestfleisch et al., 2014; Mathey et al., 2014; Masny et al., 2014a; Masny et al., 2014b; Masny et al., 2016; Kaczmarska et al., 2017; Mathey et al., 2017).

The availability of genetic diversity for any given crop will enhance the improvement of different traits (Connor $e t$ al., 2005). The hybridization is an option to extend this improvement but it is related to the knowledge of the inheritance of these traits for different genitors. Because the information about the gene effects for different traits from one set of parents could not be used to other parents, it is necessary to carry out evaluations for each potential genitor.

The present research aimed to estimate the combining ability and gene effects for plant yield, fruits number/plant, fruit weight, pulp firmness and sugar content of strawberries in order to identify the best genitors and the promising crosses, in 30 hybrids of six parents. The obtained results will be useful for the effectiveness of breeding programs in order to develop potential productive strawberries cultivars with marketable fruits.

\section{Materials and Methods}

\section{Biological material and experimental design}

The biological material consisted of 30 hybrids resulting from a complete diallel cross between six strawberry genotypes (selection 'A1' provided from Romania; 'Mira' provided from Canada; 'Alba', 'Clery', 'Marmolada' and 'Onda' provided from Italy). The selection of the parents was made according with their ripening period, yield traits, sugar content and pulp firmness of the fruits. These parents originating from different countries were chosen to suite the statistical model for this study, and were crossed in 2014.

After the extraction from the fruits the hybrid seeds have been preserved at $-15^{\circ} \mathrm{C}$ for two months, and kept at 6 ${ }^{\circ} \mathrm{C}$. The germination was carried out in a Wise Cube WGC-450 Incubator (Witeg Labortechnik $\mathrm{GmbH}$, Germany), under controlled temperature, light and humidity conditions. The hybrids seedlings of 3-4 cm high were transplanted in pots and grown in greenhouse. All hybrids and their parents were planted in the spring of 2015 using a randomized block design with four replications. The experience was conducted on an alluvial soil in Topolovățul

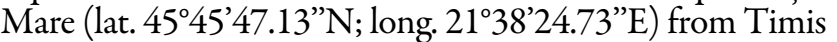
County (Romania), using plots of three rows with 25 plants (75 plants per plot) grown at $1 \times 0.20 \mathrm{~m}$.

During the growing season the classic technological works were applied (for organic farming) represented by the following measures: weed control and soil loosening by manually tilling between the plants and mechanized cultivation between rows, applying straw mulch, removal of runners during fructification, manual weeding, foliar calcium application (prevention of mildew). The crop was not irrigated and no chemical fertilizers were applied.

The climatic factors for the site location were: the average yearly temperature was around $10.7^{\circ} \mathrm{C}$ with a mean annual rainfall of $550-600 \mathrm{~mm}$. During the research period the temperatures were $1-2{ }^{\circ} \mathrm{C}$ above the average, associated with a sum of precipitation (from March to June) by 177.3 $\mathrm{mm}$ in 2014 and 142.4 in 2015.

\section{Yield and quality traits}

Measurements regarding the number of harvested fruits, fruit weight (g) and plant yield (g) were carried out using 10 plants per plot for each genotype. In order to assess the variation in the plant yield during the crop period, the harvest was carried out in five stages of 5 days intervals. A ripe fruit has been considered only the fruit that had a red uniform colour without paler or white areas.

At the full ripening time, from each plot 10 fruits were selected in order to evaluate the sugar content ( ${ }^{\circ}$ Brix) using DR201-95 (KRUSS, Germany) refractometer and pulp firmness (N) with PCE-FM200 (PCE Holding GmbH, Germany) dynamometer.

\section{Statistical analysis}

Combining ability analysis was carried out using method 1 ( $p$ parents and $p(p-1)$ hybrids), model 1 (the model with 
fixed-effects, the biological material is considered as a population about to be inferred) as suggested by Griffing (1956a, 1956b).

According to the ANOVA, the genotypic variance was partitioned into different components, including replication, GCA, SCA and reciprocal. The principles of this method are based on the following formula:

$$
x_{i j}=u+g_{i}+g_{j}+s_{i j}+r_{i j}+\frac{1}{b c} \sum_{k} \sum e_{i j k l}
$$

Griffing (1956b)

$u$ - population mean; $g_{i}\left(g_{j}\right)$ - effect of general combining ability for parent $i(j) ; s_{i j}$ - effect of specific combining ability for hybrid between parent $i$ and $j ; r_{i j}$ - reciprocal effect involving the reciprocal crosses between parent $i$ and $j$; $e_{i j k l}$ environment effect associated with individual values; $b$ number of replications; $c$ is - number of samples per replication; $k=1 . . . b ; l=1$....c.

\section{Results}

\section{Performance of the parents and crosses}

The highest variation among the parents and among the crosses was recorded for pulp firmness, while the lowest variability between the parents was registered for fruit weight, and for sugar content among crosses, respectively (Table 1).

The fruit weight ranged from 14.68 in 'Onda' $\times$ 'Clery' to 32.05 in cross 'A1' $\times$ 'Marmolada', considering that the mean of crosses (22.82) was higher than the parents one (18.40). The cross 'Clery' $\times$ 'Alba' showed the highest fruits number (37.15) followed by 'Mira' (35.15) and 'Alba' (35.03) varieties. Generally, the mean number of fruits per plant was higher for parents (30.52) to the crosses (24.28). The highest plant yield among parents was noted in 'Mira' (707 g) and 'Alba' (683 g), while among crosses it was noted in 'Marmolada' $\times$ 'Alba' (777 g) and 'A1' × 'Marmolada' $(725 \mathrm{~g})$. The difference between the mean yield of parents (559 g) and crosses (546 g) was small. Among the parents the highest sugar content was noticed in fruits of selection 'A1' ( $\left.9.35^{\circ} \mathrm{Brix}\right)$ while among crosses it was noted in 'A1' $\times$ 'Onda' (10.33 'Brix) and 'Marmolada' $\times$ 'Onda' (10.11 ${ }^{\circ}$ Brix). The sugar content of the crosses was higher to the parents except for the hybrids of selection 'A1'. The variety Marmolada had the firmness fruits followed by the crosses 'Alba' $\times$ 'Mira' and 'Mira' $\times$ 'Marmolada'. For al crosses the pulp firmness of the parents was superior to the hybrids.

Table 1. Mean values of five traits for six parents and $30 \mathrm{~F}_{1}$ strawberries diallel crosses

\begin{tabular}{|c|c|c|c|c|c|}
\hline Genotype & $\begin{array}{c}\text { Fruit } \\
\text { weight }(\mathrm{g})\end{array}$ & Fruit number/plant & $\begin{array}{c}\text { Plant } \\
\text { yield }(\mathrm{g})\end{array}$ & $\begin{array}{c}\text { Sugar } \\
\text { content }\left({ }^{\circ} \text { Brix }\right)\end{array}$ & $\begin{array}{c}\text { Pulp } \\
\text { firmness }(\mathrm{N})\end{array}$ \\
\hline 'A1' & $19.10 a$ & $25.03 b$ & $476 c$ & $9.35 a$ & $2.17 d$ \\
\hline 'Mira' & $20.15 a$ & $35.15 a$ & $707 a$ & $6.50 c$ & $3.00 b$ \\
\hline 'Alba' & $19.53 a$ & $35.03 a$ & $683 a$ & $7.20 b c$ & $2.69 b c$ \\
\hline 'Marmolada' & $18.63 a$ & $28.10 b$ & $521 b$ & $7.80 b$ & $3.51 a$ \\
\hline 'Clery' & $15.08 b$ & $32.93 a$ & $493 b c$ & $7.98 b$ & $2.62 b c$ \\
\hline 'Onda' & $17.95 a$ & $26.90 b$ & $466 c$ & $6.05 c$ & $2.39 c d$ \\
\hline 'Mira' X'Al' & $24.83 b c d e f g$ & $27.08 \mathrm{def}$ & $670 c d$ & $8.67 b c d e f g h$ & $1.82 e f g h i j$ \\
\hline 'Alba' × 'A1' & $24.88 b c d e f g$ & $28.43 c d e$ & $703 b c$ & $7.00 i j k$ & $2.40 b c d$ \\
\hline 'Marmolada' × 'Al' & $20.17 \mathrm{klm}$ & 26.45 defgh & $528 k$ & $9.14 a b c d e$ & $2.25 b c d e$ \\
\hline 'Clery' x 'A1' & $20.15 \mathrm{klm}$ & $23.83 g h i j$ & $479 \mathrm{~lm}$ & $9.02 a b c d e f$ & 1.90 efghi \\
\hline 'Onda' $\times$ 'Al' & 21.08hijklm & $23.35 h i j$ & $485 \mathrm{~lm}$ & 7.59fghijk & $2.24 b c d e$ \\
\hline 'Al' × 'Mira' & $27.05 b c d$ & $20.05 k l$ & $534 j k$ & $8.33 c$ defghi & $1.65 g h i j$ \\
\hline 'Alba' × 'Mira' & 22.95efghijk & 26.28efghi & $594 \mathrm{gh}$ & 8.00defghijk & $3.03 a$ \\
\hline 'Marmolada' × 'Mira' & $27.33 b c$ & $23.70 g h i j$ & $643 d e$ & $8.72 b c d e f g$ & $2.14 b c d e f$ \\
\hline 'Clery' × 'Mira' & $20.33 \mathrm{jklm}$ & $18.58 l$ & $375 p$ & 8.31cdefghi & $2.17 b c d e$ \\
\hline 'Onda' $\times$ 'Mira' & $25.43 b c d e f$ & $18.05 \mathrm{~lm}$ & $454 m n$ & $8.47 c$ defghi & $2.17 b c d e$ \\
\hline 'A1' × 'Alba' & 24.03 cdefgh & $26.53 \mathrm{defg}$ & $632 e f$ & $6.50 k$ & $1.43 i j k$ \\
\hline 'Mira' $\times$ 'Alba' & 23.78defghi & $24.05 f g h i j$ & 566hij & 7.88efghijk & $2.09 c d e f g$ \\
\hline 'Marmolada' × 'Alba' & $27.45 b$ & $28.48 c d e$ & $777 a$ & $7.00 i j k$ & 2.00 defgh \\
\hline 'Clery' × 'Alba' & $19.08 m n$ & $37.15 a$ & $707 b$ & 7.20hijk & $1.83 e f g h i j$ \\
\hline 'Onda' x 'Alba' & $26.02 b c d e$ & 23.53ghij & $609 f g$ & $6.53 k$ & 1.88 efghij \\
\hline 'A1' x 'Marmolada' & $32.05 a$ & $23.73 g h i j$ & $752 a$ & $8.33 c$ defghi & 1.85 efghij \\
\hline 'Mira' × 'Marmolada' & $21.63 \mathrm{ghijklm}$ & $15.20 \mathrm{mn}$ & $325 q$ & $9.67 a b c$ & $3.02 a$ \\
\hline 'Alba' × 'Marmolada' & $25.50 b c d e f$ & $17.531 \mathrm{mn}$ & $443 n o$ & 8.50cdefghi & $2.58 a b$ \\
\hline 'Clery' x 'Marmolada' & 20.65ijklm & $33.70 b$ & $694 b c$ & 7.81efghijk & $2.52 b c$ \\
\hline 'Onda' $\times$ 'Marmolada' & 22.40fghijkl & 25.70efghij & $571 h i$ & 8.23 cdefghi & $2.12 b c d e f g$ \\
\hline 'A1' x 'Clery' & $18.80 m n$ & $30.60 b c$ & $569 b i$ & 8.50cdefghi & $1.40 j k$ \\
\hline 'Mira' x 'Clery' & $16.68 n o$ & $25.25 f g h i j$ & $420 o$ & 7.50ghijk & $2.42 b c d$ \\
\hline 'Alba' $\times$ 'Clery' & 23.58efghij & $22.63 j k$ & $524 k$ & 8.33 cdefghi & 1.55 hijk \\
\hline 'Marmolada' x 'Clery' & 22.80efghijk & $18.20 \mathrm{~lm}$ & 4120 & 7.78efghijk & 1.82efghij \\
\hline 'Onda' $\times$ 'Clery' & 14.680 & $25.58 e f g h i j$ & $373 p$ & $9.43 a b c d$ & 1.91 efghij \\
\hline 'A1' × 'Onda' & $25.20 b c d e f$ & 23.83ghij & $587 g h$ & $10.33 a$ & $1.67 f g h i j$ \\
\hline 'Mira' × 'Onda' & 21.33hijklm & $29.45 c d$ & $624 e f g$ & $6.67 j k$ & $1.07 \pm 0.06 \mathrm{k}$ \\
\hline 'Alba' $\times$ 'Onda' & 23.35efghijk & $23.30 i j$ & $541 i j k$ & $8.33 c$ defghi & $1.57 \mathrm{hij}$ \\
\hline 'Marmolada' x 'Onda' & 20.75hijklm & 23.63ghij & $489 l$ & $10.11 a b$ & $2.12 b c d e f g$ \\
\hline 'Clery' × 'Onda' & 20.88hijklm & $14.70 n$ & $306 q$ & 8.08defghij & $2.27 b c d e$ \\
\hline 'Clery' $\times$ 'A1' & $24.83 b c d e f g$ & $27.08 \mathrm{def}$ & $670 c d$ & $8.67 b c d e f g h$ & $1.82 e f g h i j$ \\
\hline
\end{tabular}




\section{Analysis of variance for combining ability}

Considering the significance of the general, the specific combining ability and the reciprocal effects, it was found that the additive and non-additive gene action as well as the maternal effects were involved in the inheritance of all traits (Table 2). The values of ratio between GCA and SCA indicated that the additive effects have a higher contribution to non-additive ones in the inheritance of all five traits, especially for fruit weight and plant yield. The contributions of additive effects varied from $63 \%$ for fruits number/plant to the highest values of $84-91 \%$ for plant yield and fruit weight. The high values of the reciprocal effects suggested that the parental genotypes position played an important role in the expression of all traits in the F1 generation.

\section{GCA analysis}

The parents varied regarding the GCA effects for fruit weight from 3.07 in 'Clery' to 1.24 in 'Marmolada' variety. 'Alba' and 'Marmolada' varieties have a major influence on the increase of fruits size and the favourable additive effects of these occur with a higher intensity when these genotypes are used as female genitors. The significantly negative estimate of 'Clery' indicated that this variety possesses additive genes that reduce the fruit weight regardless of the position in the cross. The GCA effects were correlated with the fruit weight of the parents $(r=0.890)$. In the case of 'Mira' and 'A1', the low values of GCA are due to the fact that the effect of additive genes on the fruit weight was highly influenced by the position of these parents in the cross (Table 3 ).

For fruits number/plant the GCA effects ranged from -1.52 to 1.50 , and showed equal frequencies of positive and negative values. Also, these effects were not correlated $(r=$ 0.047 ) with the values of this trait from the six parents. The significantly positive effects of 'Alba' and 'Al' acted mostly when used as female parent. In the case of 'Mira' and 'Onda' the low negative values of GCA indicated that their additive genes cause a reduction of fruit number/plant especially due to maternal effects.

The amplitude of GCA effects for plant yield was relatively high with limits from -60.3 in 'Clery' to 63.4 for 'Alba'. The GCA estimation of the parents was not significant associated with their mean $(\mathrm{r}=0.270)$. The high estimate of GCA effects for 'Alba' indicated that this variety has a significant influence on the increasing of plant yield, mainly when used as a female genitor. Also, the significant positive GCA estimate of 'A1' genotype indicated that in this case the additive effects contribute to the achievement of high yields, when it will be used as pollinator. The varieties 'Clery' and 'Onda' were poor general combiners for plant yield given their negative significant GCA effects.

Regarding the sugar content the GCA effects were predominantly positive and uncorrelated $(\mathrm{r}=0.136)$ with the parents mean. 'Marmolada' variety has a high potential to increase the sugar content, and its favourable additive effects showed a good stability regardless the position in the cross (Table 4). The significant negative GCA effects of 'Alba' indicated that this variety possesses additive genes that reduce the sugar content, especially when used as a female genitor. In the case of 'Onda' the insignificant value of GCA is due to the fact that the effect of additive genes on the sugar content was highly influenced by the position in the cross. However, this gene effects contribute to an increase of sugar content only through maternal inheritance.

The estimation of GCA effects for pulp firmness ranged from -0.17 to 0.21 , and showed equal positive and negative values. These effects are highly correlated with the pulp firmness of the parents $(r=0.982)$ such that the mean of the parents can be used to establish the pairs to crossing. The significantly positive effects of 'Marmolada' and 'Mira' lead to high pulp firmness mostly when used as female parent. 'Al' and 'Onda' were poor general combiners for pulp firmness and their additive effects were highly influenced by their role in the cross.

Table 2. Mean squares of combined ANOVA for five traits in $F_{1}$ strawberries diallel crosses

\begin{tabular}{|c|c|c|c|c|c|c|}
\hline \multirow{2}{*}{$\begin{array}{c}\text { Source } \\
\text { of variation }\end{array}$} & \multirow[b]{2}{*}{ DF } & \multicolumn{5}{|c|}{ Mean square } \\
\hline & & $\begin{array}{c}\text { Fruit weight } \\
(\mathrm{g})\end{array}$ & $\begin{array}{c}\text { Fruit number/ } \\
\text { plant }\end{array}$ & $\begin{array}{c}\text { Plant } \\
\text { yield (g) }\end{array}$ & $\begin{array}{c}\text { Sugar content } \\
\left({ }^{\circ} \text { Brix }\right)\end{array}$ & $\begin{array}{l}\text { Pulp firmness } \\
(\mathrm{N})\end{array}$ \\
\hline Replication & 3 & 14.12 & 11.01 & 1552 & 1.14 & 0.07 \\
\hline GCA & 5 & $140.61^{* *}$ & $81.40^{* *}$ & $126779^{* *}$ & $6.14^{* *}$ & $1.08^{* *}$ \\
\hline SCA & 9 & $14.03^{*}$ & $47.82^{* *}$ & $24801^{* *}$ & $3.09^{* *}$ & $0.62^{* *}$ \\
\hline Reciprocal & 15 & $40.84^{* *}$ & $140.04^{* *}$ & $62066^{* *}$ & $3.42^{* *}$ & $0.77^{* *}$ \\
\hline Error & 87 & 5.56 & 4.81 & 588 & 1.15 & 0.15 \\
\hline GCA/SCA & & 5.56 & 1.70 & 5.11 & 1.98 & 1.75 \\
\hline
\end{tabular}

Table 3. Estimation of general combining ability (GCA) effects for six parents of a complete diallel cross regarding fruit weight, fruits number and plant yield in strawberries

\begin{tabular}{|c|c|c|c|c|c|c|c|c|c|}
\hline \multirow{2}{*}{ Parents } & \multicolumn{3}{|c|}{ Fruit weight $(\mathrm{g})$} & \multicolumn{3}{|c|}{ Fruits number/plant } & \multicolumn{3}{|c|}{ Plant yield $(\mathrm{g})$} \\
\hline & GCA + & GCA ${ }^{\lambda}$ & GCA & GCA ${ }^{\circ}$ & GCA $\widehat{ }$ & GCA & GCA ${ }_{+}$ & GCA ${ }^{\hat{n}}$ & GCA \\
\hline 'A1' & -0.61 & 2.60 & 0.99 & 1.54 & 0.66 & $1.10^{*}$ & 26.80 & 68.60 & $47.70^{*}$ \\
\hline 'Mira' & 1.79 & -1.18 & 0.30 & -2.96 & -0.08 & $-1.52^{* *}$ & -26.20 & -25.20 & -25.70 \\
\hline 'Alba' & 1.24 & 1.22 & $1.23^{*}$ & 3.66 & -0.66 & $1.50^{* *}$ & 112.00 & 14.80 & $63.40^{* *}$ \\
\hline 'Marmolada' & 1.62 & 0.87 & $1.24^{*}$ & -1.12 & -0.20 & -0.66 & 10.80 & 23.60 & 17.20 \\
\hline 'Clery' & -3.52 & -2.61 & $-3.07^{* *}$ & 0.16 & 1.30 & 0.73 & -86.60 & -34.00 & $-60.30^{* *}$ \\
\hline 'Onda' & -0.53 & -0.91 & -0.72 & -1.31 & -1.05 & $-1.18^{*}$ & -36.80 & -47.80 & $-42.30^{*}$ \\
\hline$S E\left(\mathrm{~g}_{\mathrm{i}}\right)$ & & & 0.61 & & & 0.51 & & & 20.45 \\
\hline
\end{tabular}


Table 4. Estimation of general combining ability (GCA) effects for six parents of a complete diallel cross regarding sugar content and pulp firmness in strawberries

\begin{tabular}{|c|c|c|c|c|c|c|}
\hline \multirow{2}{*}{ Parents } & \multicolumn{3}{|c|}{ Sugar content $\left({ }^{\circ}\right.$ Brix $)$} & \multicolumn{3}{|c|}{ Pulp firmness $(\mathrm{N})$} \\
\hline & $\mathrm{GCA}_{+}$ & GCA ${ }^{\lambda}$ & GCA & $\mathrm{GCA}_{+}$ & $\mathrm{GCA}^{\Uparrow}$ & GCA \\
\hline 'Al' & 0,08 & 0,20 & 0,14 & 0,09 & $-0,43$ & $-0,17^{* *}$ \\
\hline 'Mira' & 0,17 & $-0,12$ & 0,02 & 0,20 & 0,05 & $0,12^{*}$ \\
\hline 'Alba' & $-1,18$ & $-0,17$ & $-0,67^{* * *}$ & $-0,18$ & 0,20 & 0,01 \\
\hline 'Marmolada' & 0,31 & 0,35 & $0,33^{*}$ & 0,39 & 0,04 & $0,21^{* * *}$ \\
\hline 'Clery' & 0,11 & $-0,12$ & $-0,01$ & $-0,21$ & 0,11 & $-0,05$ \\
\hline 'Onda' & 0,50 & $-0,15$ & 0,17 & $-0,29$ & 0,03 & $-0,13^{*}$ \\
\hline$S E\left(\mathrm{~g}^{\wedge} \mathrm{i}\right)$ & & & 0.14 & & & 0.06 \\
\hline
\end{tabular}

Table 5. Estimation of specific combining ability (SCA) effects of strawberries diallel crosses regarding fruit weight, fruits number, plant yield, sugar content and pulp firmness

\begin{tabular}{|c|c|c|c|c|c|}
\hline Crosses & $\begin{array}{c}\text { Fruit } \\
\text { weight }(\mathrm{g})\end{array}$ & $\begin{array}{c}\text { Fruits } \\
\text { number/plant }\end{array}$ & $\begin{array}{l}\text { Plant yield } \\
\text { (g) }\end{array}$ & $\begin{array}{c}\text { Sugar } \\
\text { content }\left({ }^{\circ} \text { Brix }\right)\end{array}$ & $\begin{array}{c}\text { Pulp } \\
\text { firmness }(\mathrm{N})\end{array}$ \\
\hline 'Al' x 'Mira' & $1.49^{* * *}$ & -0.19 & 28.29 & 0.09 & $-0.24^{* *}$ \\
\hline 'Al' x 'Alba' & $-1.16^{* *}$ & -0.07 & -17.59 & $-0.79^{* * *}$ & 0.09 \\
\hline 'Al' x'Marmolada' & 0.47 & -0.24 & 12.69 & -0.05 & -0.03 \\
\hline 'Al' × 'Clery' & -0.76 & 0.64 & -6.46 & 0.39 & -0.10 \\
\hline 'Al' × 'Onda' & -0.04 & -0.61 & -16.93 & 0.36 & $0.29^{* *}$ \\
\hline 'Mira' x 'Alba' & $-1.39^{* * *}$ & 0.90 & -13.34 & $0.55^{* *}$ & $0.36^{* * *}$ \\
\hline 'Mira' × 'Marmolada' & -0.29 & $-2.11^{* *}$ & $-51.56^{* *}$ & $0.56^{* *}$ & 0.12 \\
\hline 'Mira' × 'Clery' & $-0.88^{*}$ & -1.43 & $-41.21^{*}$ & -0.32 & 0.17 \\
\hline 'Mira' × 'Onda' & $1.06^{* *}$ & $2.84^{* * *}$ & $77.82^{* * *}$ & $-0.88^{* *}$ & $-0.41^{* * *}$ \\
\hline 'Alba' x 'Marmolada' & 0.55 & $-2.35^{* *}$ & $-36.93^{*}$ & -0.02 & -0.01 \\
\hline 'Alba' × 'Clery' & $0.79^{*}$ & $2.81^{* * *}$ & $65.41^{* * *}$ & $0.41^{*}$ & $-0.28^{* *}$ \\
\hline 'Alba' × 'Onda' & $1.20^{* *}$ & -1.29 & 2.44 & -0.15 & -0.15 \\
\hline 'Marmolada' × 'Clery' & $1.17^{* *}$ & $1.57^{*}$ & $60.69^{* * *}$ & $-0.82^{* * *}$ & -0.06 \\
\hline 'Marmolada' x 'Onda' & $-1.91^{* * *}$ & $2.65^{* * *}$ & 15.10 & 0.33 & -0.01 \\
\hline 'Clery' × 'Onda' & -0.32 & $-3.59^{* * *}$ & $-78.43^{* * *}$ & 0.34 & $0.28^{* *}$ \\
\hline$S E\left(s^{\wedge}{ }_{i j}\right)$ & 0.39 & 0.73 & 16.70 & 0.20 & 0.09 \\
\hline
\end{tabular}

\section{SCA analysis}

According to the data from Table 5 five positive significant SCA effects were observed for fruit weight, with higher values for 'Al' $\times$ 'Mira', 'Alba' $\times$ 'Onda' and 'Marmolada' $\times$ 'Clery'. There is a high probability that the offspring of these crosses will produce larger fruits. In addition, four crosses ('Marmolada' $x$ 'Onda', 'Mira' $\times$ 'Alba', 'Al' $\times$ 'Alba' and 'Mira' $\times$ 'Clery') had negative SCA effects, associated with low values of this trait in the progeny.

For fruits number/plant, the crosses: 'Mira' $\times$ 'Onda', 'Alba' $\times$ 'Clery', 'Marmolada' $\times$ 'Onda' and 'Marmolada' $\times$ 'Clery' had high positive SCA effects which provided a large number of harvestable fruits in the offspring. Regarding the significant negative SCA effects of 'Clery' $x$ 'Onda, 'Alba' $x$ 'Marmolada' and 'Mira' $\times$ 'Marmolada', there is a low probability to asset progenies of them with a high fruits number/plant.

Significant positive SCA effects were found for plant yield, in 'Mira' $\times$ 'Onda', 'Alba' $\times$ 'Clery' and 'Marmolada' $\times$ 'Clery' crosses, which are worthy of being considered in order to improve the yield. The crosses: 'Clery' $\times$ 'Onda', 'Mira' $\times$ 'Marmolada', 'Mira × Clery' and 'Alba' $x$ 'Marmolada' had negative SCA effects, associated with low yields in the progeny.

As regards to the high significant SCA effects for sugar content found in 'Mira' $\times$ 'Marmolada', 'Mira' $\times$ 'Alba' and 'Alba' $\times$ 'Clery', there is a high probability that the offspring of these crosses will produce sweeter fruits.

For pulp firmness, 'Mira' $\times$ 'Alba', 'A1' $\times$ 'Onda' and 'Clery' $\times$ 'Onda' crosses are favourable for the selection of genotypes with firm fruits.

\section{Discussion}

The results of this study illustrated that both general and specific combining effects are important in the genetic control of all five suited traits, with a major contribution of additive genes compared to the dominant and epistatic ones. However, the predominance of additive effects in the inheritance of different traits in strawberries was reported by various researchers: the ascorbic acid content (Lundergan and Moore, 1975); the fruit ripening time (Hortyński, 1987); the tolerance to Verticillium dabliae (Masny et al., 2014b); the fruit firmness (Shaw et al., 1987; Yashiro et al., 2002; Masny et al., 2005); the fruit weight (Simpson and Sharp, 1988; Masny et al., 2005; Masny et al., 2014a); the susceptibility to grey mould (Masny et al., 2005); plant yield 
522

(Simpson and Sharp, 1988). The importance of additive and non-additive effects for the inheritance of the studied traits varies depending on the parents, in agreement with the findings of Sherman et al. (1967).

The present study and also a large number of other studies suggested that different traits in strawberries are highly inheritable: fruit size (Comstock et al., 1958; Watkins et al., 1970; Spangelo et al., 1971; Whitaker et al., 2012; Mishra et al., 2015); plant yield, fruit number/plant, sugar content (Mishra et al., 2015). In essence, there is a strong potential to improve this traits by selection of the best parents.

The significance of reciprocal effects indicated that an important role is played by the determination of parents to be used as donors or recipients of pollen in the cross. According with the present results and with Bestfleisch et al. (2014) findings the full diallel design might be useful for the analysis of breeding potential for different strawberries genotypes.

The GCA effects of the parents for fruit weight and pulp firmness can be predicted on the basis of their mean, because the GCA estimation was highly correlated with parental means. This has been also observed for fruit weight by Żurawicz and Masny (2014). Therefore, these effects are important for the selection of parents in order to improve those traits.

High significant SCA effects of the cross 'Mira' $x$ 'Onda' between parents with high GCA for plant yield, can be a result of the interaction of the genes of both parents, and might be due to presence of high magnitude of nonadditive especially complementary epistatic effects (Singh $e t$ al., 2011). Therefore, according to Masny et al. (2016) one should expect that the productivity of the derived hybrids will be significantly higher than the sum of parent's GCA effects.

Regarding the crosses 'Alba' $\times$ 'Clery' and 'Marmolada' $x$ 'Clery' the high positive SCA effects are associated with high and low GCA effects of the parents. According to the results of Joshi and Sharma, (1984) and Singh et al. (1986), intermating between crosses followed by selection may be useful in order to obtain desirable genotypes in crosses from parents with high $\times$ low and low $\times$ low GCA.

The cross 'Al' $\times$ 'Alba' had a low SCA effects for plant yield, even both parents are good combiners. This confirm the findings of Zhang et al. (2015) that the hybrids from two parents with high GCA always showed better hybrid performance even though their SCA were low.

The combining ability of the parents shoved that none of them excelled for all traits in positive direction, being necessary to test the GCA effects of new strawberries genotypes, as suggested by Kaczmarska et al. (2017). As such, multiple crossings are necessary in order to develop valuable cultivars for both yields and quality traits.

\section{Conclusions}

The predominant role of additive over non-additive effects for the studied traits indicated that is possible to develop new valuable strawberries genotypes. The genotypes 'A1' and 'Alba' showed a higher concentration of favourable alleles for plant yield and fruits number, and they will allow the increase of plant yield when used as a male and of fruit number when used as a female genitor. The variety 'Marmolada' was a good general combiner for sugar content, pulp firmness and fruit weight, with a significant effect when used as a female genitor. These parents might be used in hybridization in order to accelerate the genetic improvement of some yield and quality traits in strawberry.

\section{References}

Ara T, Haydar A, Hayatmahamud, Khalequzzaman KM, Hossain MM (2009). Analysis of the different parameters for fruit yield and yield contributing characters in strawberry. International Journal Sustainable Crop Production 4:15-18.

Bestfleisch M, Möhring J, Hanke M, Peil A, Flachowsky H (2014). A diallel crossing approach aimed on selection for ripening time and yield in breeding of new strawberry (Fragaria $\times$ ananass Duch.) cultivars. Plant Breeding 133 (1):115-120.

Capocasa F, Scalzo J, Mezzetti B, Battino M (2008). Combining quality and antioxidant attributes in the strawberry: The role of genotype. Food Chemistry 111:872-878.

Carp N, Ciulca S (2016). Study of some yield components in different cultivars of strawberry. Journal of Agricultural Research 48(2):1620.

Comstock RE, Kelleher T, Morrow EB (1958). Genetic variation in an asexual species of the garden strawberry. Genetics 43:634-646.

Connor AM, Stephens MJ, Hall HK, Alspach PA (2005). Variation and heritabilities of antioxidant activity and total phenolic content estimated from a red raspberry factorial mating design. Journal of the American Society for Horticultural Science 130(4):534542.

Cruz CD, Vencovsky R (1989). Comparison of some methods of diallel analysis. Revista Brasileira de Genética 12:425-438.

Daubeny HA (1961). Powdery mildew resistance in strawberry progenies. Canadian Journal of Plant Science 41:239-243.

Davik J, Honne BI (2005). Genetic variance and breeding values for resistance to a wind-borne disease [Sphaerotheca macularis (Wallr. Ex Fr.)] in strawberry (Fragaria ananassa Duch.) estimated by exploring mixed and spatial models and pedigree information. Theoretical and Applied Genetics 111:256-264.

Doving A, Mage F, Vestrheim S (2005). Methods for testing strawberry fruit firmness: a review. Small Fruits Review 4:11-34.

Eshghi S, Tafazoli E (2007). Possible role of cytokinins in flower induction in strawberry. American Journal of Plant Physiology 2:167-174.

Falconer DS (1989). Introduction of quantitative genetics, $3^{\text {rd }}$ edn. Longaman, Essex.

Fehr WR (1993). Principles of cultivar development: development of hybrid cultivars, vol 1. Macmillan Publishing Company, New York.

Fort SB, Shaw DV (2000). Genetic analysis of strawberry root system traits in fumigated and nonfumigated soils. I. Inheritance patterns of strawberry root system characteristics. Journal of the American Society for Horticultural Science 125:318-323.

Griffing B (1956a). A generalised treatments of diallel crosses in quantitative inheritance. Heredity 10:31-50.

Griffing B (1956b). Concept of general and specific combining ability in relation to diallel crossing systems. Australian Journal of Biological 
Sciences 9:463-493.

Hakizimana F, Ibrahim AMH, Langham MAC, Haley SD, Rudd JC (2004). Diallel analysis of wheat streak mosaic virus resistance in winter wheat. Crop Science 44:89-92.

Hancock JF (1999). Strawberries. CAB International, Wallingford, Oxford, UK.

Hancock JF, Sjulin TM, Lobos GA (2008). Strawberry. In: Hancock JF (Ed). Temperate fruit crop breeding. Germplasm to genomics. Springer Netherlands pp 393-437.

Hill J, Becker HC, Tigerstedt PMA (1998). The diallel cross: the ultimate mating design. In: Quantitative and ecological aspects of plant breeding. Chapman and Hall, UK, London pp 89-117.

Hortyński JA (1987). Dziedziczenie niektórych cech ilościowych truskawki (Fragaria $\times$ ananassa Duch.). Metody i problemy oszacowań. [Methods and problems of estimation]. Wyd. AR Lublin.

Hortyński JA, Żebrowska J, Gawroński J, Hulewicz T (1991). Factors influencing fruit size in the strawberry (Fragaria ananassa Duch.). Euphytica 56:67-74.

Hou ZX, Huang WD (2005). Immunohistochemical localization of IAA and ABP1 in strawberry shoot apexes during floral induction. Planta 222:678-687.

Hsu CS, Watkins R, Bolton AT, Spangelo LPS (1969). Inheritance of resistance to powdery mildew in the cultivated strawberry. Canadian Journal of Genetics and Cytology 11:426-438.

Kaczmarska E, Gavronski J, Jablonska-Rys E, Zalewska-Korona M, Radzki W, Slawinska A (2017). General combining ability and heterosis regarding the phytochemical properties in strawberry (Fragaria $\times$ ananassa) hybrids. Plant Breeding 136:111-118.

Joshi AK, Sharma GS (1984). Genetics of flag leaf area in wheat Triallel analysis. Indian Journal of Genetics 44:399-405.

Lundergan CA, Moore JN (1975). Inheritance of ascorbic acid content and color intensity in fruits of strawberry (Fragaria $\times$ ananassa Duch.). Journal of the American Society for Horticultural Science 100(6):633-635.

MacLachlan JB (1978). Data on the inheritance of resistance to powdery mildew in the cultivated strawberry. Scientia Horticulturae 8:43-49.

Masny A, Mądry W, Żurawicz E (2005). Combining ability analysis of fruit field and fruit quality in ever-bearing strawberry cultivars using an incomplete diallel cross design. Journal of Fruit and Ornamental Plant Research 13:5-17.

Masny A, Mądry W,Żurawicz E (2014a). Combining ability of selected dessert strawberry cultivars with different fruit ripening periods. Acta Scientiarum Polonorum Hortorum Cultus 13(1):67-78.

Masny A, Żurawicz E, Pruski K, Mądry W (2014b). Combining ability analysis in 10 strawberry genotypes used in breeding cultivars for tolerance to Verticilium Wilt. J. Journal of the American Society for Horticultural Science 139(3): 275-281.

Masny A, Pruski K, Żurawicz E, Mądry W (2016). Breeding value of selected dessert strawberry (Fragariax ananassa Duch.) cultivars for ripening time, fruit yield and quality. Euphytica 207: 224-243.

Mathey MM, Mookerjee S, Mahoney L, Finn CE, Hancock JF, Serçe S,
Davis T, Stewart P, Whitaker VM, Jamieson AR, Bassil NV, Amaya I, Denoyes B, Hummer KE, Sargent D, van de Wegand E, Iezzoni A (2014). Using general and specific combining ability to further advance strawberry (Fragaria sp.) breeding. Acta Horticulturae 1049:193-200.

Mathey MM, Mookerjee S, Mahoney LL, Gunduz K, Rosyara U, Hancock JF, Stewart PJ, Whitaker VM, Bassil NV, Davis TM, Finn CE (2017). Genotype by environment interactions and combining ability for strawberry families grown in diverse environments. Euphytica 213:112.

McNicol RJ, Gooding HJ (1979). Assessment of strawberry clones and seedlings for resistance to Sphaerotheca macularis. Horticulture Research 19:35-41.

Mishra PK, Ram RB, Kumar N (2015). Genetic variability, heritability, and genetic advance in strawberry (Fragaria $\times$ ananassa Duch.). Turkish Journal of Agriculture and Forestry 39:451-458.

Paszko D, Pawlak J, Wróblewska W (2014). Yield of two strawberry cultivars depending on the cropping method on the example of a commercial plantation in a specialized horticultural farm. Acta Scientiarum Polonorum Hortorum Cultus 13(6):149-159.

Salentijn EMJ, Aharoni A, Schaart JG, Boone MJ, Krens FA (2003). Differential gene expression analysis of strawberry cultivars that differ in fruit-firmness. Physiologia Plantarum 118:571-578.

Shaw DV, Bringhurst RS, Voth V (1987). Genetic variation for quality traits in an advanced cycle breeding population of strawberries. Journal of the American Society for Horticultural Science 112:699702.

Shaw DV (1988). Genotypic variation and genotypic correlations for sugars and organic acids of strawberries. Journal of the American Society for Horticultural Science 113:770-774.

Shaw DV (1991). Recent advances in the genetics of strawberries. In: Dale A, Luby JJ (eds.) The Strawberry into the 21st Century Timber Press, Portland, Oregon pp 76-83.

Sherman WB, Janick J, Erickson HT (1967). Inheritance of fruit size in strawberry. Proceedings of the American Society for Horticultural Science 89: 309-317.

Simpson DW (1987). The inheritance of mildew resistance in everbearing and day-neutral strawberry seedlings. Journal of the American Society for Horticultural Science 62:329-334.

Singh RK, Ahmed Z, Singh YP, Singh KN (1986). Combining ability studies for some metric traits in bread wheat. Indian Journal of Genetics 46:304-310.

Singh M, Tomar A, Mishra CN, Srivastava SBL (2011). Genetic parameters and character association studies in Indian mustard. Journal ofOilseed Brassica 2(1):35-38.

Simpson DW, Sharp DS (1988). The inheritance of fruit yield and stolon production in everbearing strawberries. Euphytica 38:65-74.

Spangelo LPS, Watkins R, Hsu CS, Fejer SO (1971). Combining ability analysis in the cultivated strawberry. Canadian Journal of Plant Science 51:377-383.

Ukalska J, Mądry W, Ukalski K, Masny A, Żurawicz E (2006). Patterns of variation and correlation among traits in a strawberry germplasm (Fragaria $\times$ ananassa Duch.). Journal of Fruit and Ornamental 
524

Plant Research 14:5-22.

Vij S, Tyagi AK (2007). Emerging trends in the functional genomics of the abiotic stress response in crop plants. Plant Biotechnology Journal 5:361-380.

Watkins R, Spangelo LPS, Bolton AT (1970). Genetic variance components in cultivated strawberry. Canadian Journal of Genetics and Cytology 12:52-59.

Whitaker VM, Osorio LF, Hasing T (2012). Estimation of genetic parameters for 12 fruit and vegetative traits in the University of Florida strawberry breeding population. Journal of the American
Society for Horticultural Science 137(5):316-324.

Yashiro K, Tomita K, Ezura H (2002). Is it possible to breed strawberry cultivars which confer firmness and sweetness? Acta Horticulturae 567:223-225.

Zhang X, Liangiie LV, Chai LV, Baojian G, Rugen X (2015). Combining ability of different agronomic traits and yield components in hybrid barley. PLoS ONE 10:6.

Żurawicz E, Masny A (2014). 'Granda rosa' - new polish strawberry cultivar. Acta Horticulturae 1049:849-852. 